\title{
Atrophic gastric changes in both Helicobacter felis and Helicobacter pylori infected mice are host dependent and separate from antral gastritis
}

\author{
T Sakagami, M Dixon, J O'Rourke, R Howlett, F Alderuccio, J Vella, T Shimoyama, \\ A Lee
}

\begin{abstract}
Background/Aims-The role of host factors has been neglected in studies of the pathogenesis of Helicobacter associated disease. The aim of this study was to assess the response of different mouse strains to infection with a single strain of Helicobacter felis.

Method-Six strains of inbred mice were infected with the identical $\boldsymbol{H}$ felis culture and were killed at one month, two months, and six months after infection to assess histopathological changes. In addition, two strains of mice were infected with a mouse adapted strain of $H$ pylori and
\end{abstract} examined at six months after infection.

Results-In SJL, C3H/He, DBA/2, and C57BL/6 infected mice, severe to moderlate chronic active gastritis was observed only in the body of the stomach, which increased in severity over time with specialised cells in the body glands being replaced. As the severity of this damage in the body increased and atrophic changes were seen, the level of bacterial colonisation of the antrum decreased. In contrast, in BALB/c and CBA mice, there was only mild gastritis in the antrum, no remarkable changes were detected in their body mucosa, and no atrophy was seen over time. In both these strains of mice, heavy bacterial colonisation was seen, which tended to increase over the period of the experiment. Of particular importance in this experiment was that bacterial colonisation was mainly restricted to the antrum yet the atrophy, when present, was only observed in the body of the stomach. $\mathrm{H}$ pylori infected $\mathrm{C} 3 \mathrm{H} / \mathrm{He}$ mice showed moderate colonisation of the antrum, which persisted up to six months with little development of atrophy. In contrast, $H$ pylori in C57BL/6 mice showed excellent colonisation of the antrum at two months but six months after infection there was moderate to severe body atrophy, which was associated with a loss of bacteria from the antrum.

Conclusions-These findings challenge current concepts of the development of Helicobacter induced atrophy in that active chronic gastritis of antrum or the body mucosa, or both, is not a prerequisite. They also suggest an autoimmune basis for the pathology although no autoantibody or antibody to the $\mathrm{H}^{+} / \mathrm{K}^{+}$ ATPase was detected. Loss of infecting helicobacters from the stomach together with development of an atrophic gastritis in the body of the stomach is similar to the pattern found in certain $\mathrm{H}$ pylori infected human subjects.

(Gut 1996; 39: 639-648)

Keywords: Helicobacter pylori, atrophy, mouse model, host factors, gastritis.

In 1983 Pelayo Correa proposed a sequence of events leading to the development of gastric adenocarcinoma. ${ }^{1}$ Active chronic gastritis caused by some unexplained environmental factor progressed to multifocal atrophic gastritis with loss of chief cells and parietal cells and the appearance of intestinal metaplasia. Increased cell turnover in the atrophic stomach, together with the hypochlorhydria resulting from parietal cell loss, created a gastric milieu susceptible to the effect of carcinogens possibly generated by overgrowing of nitrifying bacteria. If certain dietary factors were present, for example, high salt intake and low vitamin $C$ consumption the scene was set for the development of adenocarcinoma. The discovery of Helicobacter pylori provided the missing link in the Correa pathway. Here was the environmental factor responsible for the active/chronic gastritis. Epidemiological evidence has accumulated providing enough proof of $H$ pylori as a causal agent in gastric cancer that a working party of the International Agency for Research on Cancer (IARC) classified the bacterium as a Class I carcinogen. ${ }^{2}$ The concept of a continuum of $H$ pylori induced inflammation worsening in severity from active/chronic gastritis to atrophic gastritis is now generally accepted as the scenario leading to gastric cancer. Variation in the severity of the gastritis has been explained by the existence of particular virulent strains of $H$ pylori, that carry the marker gene cagA. ${ }^{34}$ Consistent with this concept, cagA positive strains of $H$ pylori induce greater recruitment of neutrophils via increased production of the inflammatory cytokine interleukin 8 by gastric epithelial cells. ${ }^{5}$ Another feature of atrophic gastritis is that $H$ pylori tends to be lost from the stomach in advanced disease. ${ }^{7}$ Some claimed the lack of association of concurrent $H$ pylori infection and atrophy as evidence against a causal link. Others suggested this was due to a change in the gastric environment such that it had become hostile to survival of the bacterium in particular, a lack of attachment 
sites due to intestinalisation of the gastric mucosa. The role of the host factors in the scenario leading to gastric atrophy has been largely ignored. In 1993 we published an animal model of atrophic gastritis, namely longterm infection in a conventional strain of Quackenbush/Swiss (QS) mice with a close relative of $H$ pylori, Helicobacter felis. ${ }^{8}$ Subsequently we examined longterm infection of the same strain of bacterium in a different strain of mice, BALB/c. These animals had no gastritis but after 22 months did develop lesions equivalent to low grade B-cell lymphomas. ${ }^{9} \mathrm{~A}$ striking feature of these two experiments was the completely different pathology seen in the two strains of mice to longterm exposure to the same bacterium. Differences in host factors were the only explanation. Therefore it was decided to examine the development of gastritis in a number of different strains of mice, to explore the development of atrophic gastritis, and the influence of these host factors. Six strains were selected from the same animal house to eliminate differences due to variations in intestinal microflora. Special emphasis in this study was given to the development of antral gastritis and a mapping of bacterial colonisation as these had not previously been assessed in longterm studies and were important with respect to $H$ pylori induced atrophy in the human. The development of an $H$ pylori mouse model later in this study, using a human strain of the bacterium adapted by multiple passage in mice over six months, allowed us to find out if $H$ pylori would induce atrophy in a mouse model.

\section{Methods}

ANIMALS

Six week old female inbred Specific Pathogen Free (SPF) mice of six different strains were obtained from the same institute (Walter and Elisa Hall Institute, Melbourne, Australia), the detail of these mice strains is shown in Table I.

All mice were maintained in the animal house at the School of Microbiology and Immunology, The University of New South Wales. They were fed a diet of sterilised commercial pellets (Lab Feed, Sydney, NSW) and drinking water was given ad libidum.

For each strain, 24 mice were infected with $H$ felis and six mice served as uninfected controls. In addition, groups of $10 \mathrm{C} 3 \mathrm{H} / \mathrm{He}$ and C57/BL/6 mice were infected with $H$ pylori. All protocols involving animal experi-

TABLE I Strains of mice used for $\mathrm{H}$ felis colonisation and their $H-2$ complexes

\begin{tabular}{llllllll}
\hline & \multicolumn{7}{c}{$H-2$ complex } \\
\cline { 3 - 8 } Strain & Haplotype & $K$ & $D$ & $A a$ & $A b$ & $E a$ & $E b$ \\
\hline C3H/He & k & k & k & k & k & k & k \\
CBA & k & k & k & k & k & k & k \\
DBA/2 & d & d & d & d & d & d & d \\
BALB/c & d & d & d & d & d & d & d \\
C57BL/6 & b & b & b & b & b & - & b \\
SJL & s & s & s & s & s & - & s \\
\hline
\end{tabular}

mentation were approved by the Animal Care and Ethics Committee at the University of New South Wales.

BACTERIA

$H$ felis, strain CS1 (ATCC 49179), originally isolated from cat stomach, and $H$ pylori, strain SS1, a cagA +ve, vacA +ve human isolate adapted to colonise the mouse stomach, were grown on Campylobacter Selective Agar consisting of sterile horse blood ( $5 \% \mathrm{v} / \mathrm{v})$ in Blood Agar Base No 2 (Oxoid Ltd, Basingstoke, UK) containing $10 \mathrm{mg} / \mathrm{l}$ Vancomycin (Sigma Chemical Co, St Louis, MO.), $5 \mathrm{mg} / \mathrm{l}$ Trimethoprim lactate (Sigma), 2500 IU/1 Polymyxin B (Sigma), and $5 \mathrm{mg} / \mathrm{l}$ Amphotericin B (ER Squibb and Sons, Princetown, NJ). The plates were incubated in an anaerobic jar (Oxoid) with microaerophilic gas generating kit (Code no BR 56, Oxoid) for two days at $37^{\circ} \mathrm{C}$. $\mathrm{H}$ felis was harvested from plates and suspended in brain-heart infusion broth (BHI) (Oxoid) and the final concentration was adjusted to approximately $10^{9}$ bacteria/ml with BHI broth. The $H$ pylori isolate was inoculated into BHI broth supplemented with $5 \%$ horse serum and antibiotics as above and incubated under microaerophilic conditions with agitation for two days at $37^{\circ} \mathrm{C}$. The cells were then centrifuged at $5000 \mathrm{rpm}$ for 10 minutes and the final concentration adjusted to approximately $10^{9}$ bacteria $/ \mathrm{ml}$. Mice were inoculated intragastrically three times in five days with $0 \cdot 1$ $\mathrm{ml}$ of bacterial suspension using a polyethylene stomach catheter $(0.58 \mathrm{~mm}$ internal diameter $\times 0.97 \mathrm{~mm}$ outer diameter). Uninfected control animals were kept for the same period.

\section{EXPERIMENTAL SCHEDULE}

For each strain of mice, four infected animals were examined at one month, and 10 at two months and six months. Three control mice were examined at the latter two time points.

\section{Assessment of pathology and colonisation}

The stomachs were cut into strips and fixed in $10 \%$ formal buffered saline, embedded in paraffin wax, and $4 \mu \mathrm{m}$ thick sections were cut. These sections were stained with haematoxylin and eosin for histopathological assessment and May Grunwald-Giemsa stain for assessment of colonisation. The degree of gastric inflammation and architectural changes of gastric mucosa were assessed in the haematoxylin and eosin sections. Slides were inspected 'blind'. That is, the label of all slides were masked, slides were randomly mixed and relabelled. The total number of slides was 216 . All slides were scored independently by two of us (TS and $M D$ ), interobserver differences were found to be negligible. The degree of gastritis was determined using the scoring system described in Table II. Antrum and body were each graded for 'chronic inflammation' characterised by infiltration of mononuclear cells 'activity' by presence of polymorphonuclear leucocytes, and atrophy by loss of specialised 
TABLE II Degree of chronic inflammation, activity, and architectural changes of gastric mucosa

\begin{tabular}{|c|c|c|c|}
\hline Grade & Chronic inflammation & Activity & Atrophic changes \\
\hline 0 & No increase in inflammatory cell & No increase in inflammatory cell & No loss of specialised cells \\
\hline 1 & $\begin{array}{l}\text { Uniform infiltration of lamina propria } \\
\text { by lymphocytes, plasma cells, and some } \\
\text { eosinophils }\end{array}$ & $\begin{array}{l}\text { Scattered neutrophils in the lamina } \\
\text { propria with no leucopedesis in the } \\
\text { region of the gastric pits }\end{array}$ & $\begin{array}{l}\text { Mild loss of specialised cells in glands } \\
\text { (chief cells and parietal cells) }\end{array}$ \\
\hline 2 & $\begin{array}{l}\text { Moderately dense infiltration of the } \\
\text { lamina propria by lymphocytes and } \\
\text { plasma cells }\end{array}$ & $\begin{array}{l}\text { Moderate number of neutrophils in the } \\
\text { lamina propria with microabscess in the } \\
\text { region of gastric pits }\end{array}$ & $\begin{array}{l}\text { Moderate loss of specialised cell in } \\
\text { gland }\end{array}$ \\
\hline 3 & $\begin{array}{l}\text { Very dense lymphoplasmo-cell } \\
\text { infiltration on the lamina propria }\end{array}$ & $\begin{array}{l}\text { Extensive neutrophils in the lamina } \\
\text { propria with obvious cryptitis }\end{array}$ & Severe loss of specialised cell in gland \\
\hline
\end{tabular}

cells - that is, chief and parietal cells (nil $=0$, mild $=1$, moderate $=2$, severe $=3$ ). The degree of colonisation was assessed by semiquantative analysis of bacteria in the antrum, body, and squamo-columnar junction (nil $=0,1-2$ cell/ crypt $=1,3-10 \mathrm{cell} / \mathrm{crypt}=2,11-20=3,>21 \mathrm{cell} /$ crypt $=4)$. Colonisation in all 216 slides were also assessed 'blind' by two of us (TS and JO).

IMMUNOASSAY

Systemic IgG antibody against $H$ felis in the serum was measured using an enzyme linked immunosorbent assay (ELISA). Microtitre plates were coated with whole cell sonicates of $H$ felis (ATCC 49179) $(100 \mu \mathrm{g} / \mathrm{ml})$ as the antigen. Sample sera were diluted to 100 times with blocking buffer and specific antibody against $H$ felis detected by using alkaline phosphatase conjugated antimouse IgG (GibcoBRL, Gaithersberg, MD) as the second antibody and disodium $p$-nitrophenyl phosphate, disodium (Sigma) as the substrate. The optical density (OD) was measured by reading absorbances at $405 \mathrm{~nm}$ using a photometer (BIO-RAD plate reader, Hercules, CA). All assays were done at the same time permitting valid comparative studies.

\section{ASSESSMENT OF AUTOANTIBODY}

\section{H/K-ATPase ELISA}

Anti-H/K ATPase antibodies in mouse sera were detected by an ELISA adapted from Chuang et al. ${ }^{10}$ Porcine derived $\mathrm{H} / \mathrm{K}$-ATPase, comprising both $\alpha$ and $\beta$ subunits, was obtained from Dr F Alderuccio of Monash Medical School, Melbourne, Australia and Dr $\mathrm{H}$ Larsson of Astra Hassle AB, Sweden. Polyvinyl chloride microtitre plates (Dynatech Laboratories Inc, Acacia Ridge, QLD) were coated with $50 \mu \mathrm{l}$ of purified H/K-ATPase at a concentration of $1 \mu \mathrm{g} / \mathrm{ml}$ (Melbourne derived pump) and $6.25 \mu \mathrm{g} / \mathrm{ml}$ (Astra derived pump) in $0.5 \mathrm{M}$ carbonate-bicarbonate buffer $\mathrm{pH} 9.6$ for four hours at room temperature. Plates were blocked with $1 \%$ bovine serum albumin (BSA) in phosphate buffered saline (PBS) overnight at $4^{\circ} \mathrm{C}$. Sera was diluted $1: 50$ in PBS+0.05\% TWEEN-20. Bound antibody was detected by addition of $50 \mu$ of antimouse IgG biotinylated species antibody from goat (Amersham International, Little Chalfont, UK) at a dilution of $1: 500$ in $0.1 \% \mathrm{BSA}$ in PBS, followed by $50 \mu \mathrm{l}$ of streptavidinbiotinylated horseradish peroxidase complex (Amersham) at a dilution of $1: 500$ in $0.1 \%$
BSA in PBS. Incubations were performed at room temperature for 60 minutes except the streptavidin-biotinylated complex, which was performed for 30 minutes. Between incubations, plates were washed three times with PBS $+0 \cdot 05 \%$ TWEEN-20. Peroxidase activity was detected by addition of $100 \mu$ l of substrate, containing $\quad 0.2 \mathrm{mg} / \mathrm{ml} \quad O$-phenyldiamine (Sigma) in methanol and $0.006 \% \mathrm{H}_{2} \mathrm{O}_{2}$ for 20-30 minutes in the dark. The reaction is stopped with $50 \mu \mathrm{l} \mathrm{H}_{2} \mathrm{SO}_{4}$, and the plate read at $490 \mathrm{~nm}$. Controls included normal mouse sera previously defined positive and negative for gastric $\mathrm{H} / \mathrm{K}-\mathrm{ATPa} e$ and parietal cell reactivity from mice with and without neonatal thymectomy induced autoimmune gastritis. ${ }^{11}$ In addition, monoclonal antibodies IH9 and 2B6 specific for the $\alpha$ and $\beta$ subunit of gastric $\mathrm{H} / \mathrm{K}-\mathrm{ATPase}$ respectively, were also used.

\section{Detection of parietal cell autoantibodies}

Mouse sera were assayed for parietal cell autoantibodies by indirect immunofluorescence. Five micron sections of formalin fixed paraffin wax embedded normal mouse stomach were cut, dewaxed in Histol, washed twice in $100 \%$ ethanol and once in water. The sections were incubated with sera diluted 1:50 in PBS for 60 minutes at room temperature. Slides were washed three times, firstly in PBS followed by PBS+0.05\% TWEEN-20 and finally PBS. All wash steps were performed at room temperature for five minutes on a shaker. Bound antibody was detected by incubation with FITC-sheep antimouse Ig (Silenus Laboratories, Hawthorn, Victoria) at 1:50 in PBS for 45-60 minutes at room temperature in the dark. All incubation steps were carried out in a humidity chamber. Sections were washed three times as above, mounted under a cover slip with Fluorosave Reagent (Calbiochem Behring Corp, San Diego, CA), and examined by fluorescence microscopy at an excitation wavelength of 440-500 nm. Monoclonal antibodies $1 \mathrm{H} 9$ and 2B6, specific for the $\alpha$ and $\beta$ subunits of the H/K-ATPase respectively, and sera from normal and neonatal thymectomy mice were used as controls.

\section{Results}

LONGTERM H FELIS INFECTION

\section{Histopathology}

Table III shows the differences in the severity of gastritis between various strains of mice 
TABLE III Details of gastritis in various strains

\begin{tabular}{|c|c|c|c|c|c|c|c|}
\hline \multirow[t]{2}{*}{ Strain } & \multirow{2}{*}{$\begin{array}{l}\text { Length of } \\
\text { infection } \\
\text { (months) }\end{array}$} & \multicolumn{3}{|l|}{ Antrum } & \multicolumn{3}{|l|}{ Body } \\
\hline & & Inflammation & Activity & Atrophy & Inflammation & Activity & Atrophy \\
\hline \multirow[t]{2}{*}{ SJL } & $\begin{array}{l}1 \\
2\end{array}$ & $\begin{array}{l}1.3 /- \\
0.9 / 0\end{array}$ & $\begin{array}{l}1 /- \\
0.7 / 0\end{array}$ & $\begin{array}{l}0 /- \\
0 / 0\end{array}$ & $\begin{array}{l}2 /- \\
1 \cdot 6 / 0\end{array}$ & $\begin{array}{l}1 \cdot 2 /- \\
1 \cdot 4 / 0\end{array}$ & $\begin{array}{l}2 /- \\
2 \cdot 1 / 0\end{array}$ \\
\hline & 6 & $0.8 / 0$ & $0 \cdot 1 / 0$ & $0 / 0$ & $2 / 0$ & $1 \cdot 3 / 0$ & $2 \cdot 1 / 0$ \\
\hline \multirow[t]{3}{*}{$\mathrm{C} 3 \mathrm{H} / \mathrm{He}$} & 1 & $0 /-$ & $0 /-$ & $0 /-$ & $0.7 /-$ & $0 \cdot 2 /-$ & $1 /-$ \\
\hline & 2 & $0 \cdot 1 / 0$ & $0 / 0$ & $0 / 0$ & $1 \cdot 1 / 0$ & $0.9 / 0$ & $1 / 0$ \\
\hline & 6 & $0.7 / 0$ & $0.2 / 0$ & $0 / 0$ & $2 \cdot 2 / 0 \cdot 3$ & $1 \cdot 4 / 0 \cdot 3$ & $2 \cdot 5 / 0 \cdot 6$ \\
\hline \multirow[t]{3}{*}{ DBA } & 1 & $0.7 /-$ & $0.7 /-$ & $0 /-$ & $1 /-$ & $0.2 /-$ & $0.5 /-$ \\
\hline & 2 & $0 \cdot 2 / 0$ & $0 \cdot 2 / 0$ & $0 / 0$ & $0.9 / 0$ & $1 / 0$ & $1 / 0$ \\
\hline & 6 & $1 / 1$ & $0 \cdot 1 / 0$ & $0 / 0$ & $2 \cdot 1 / 1$ & $0.7 / 0$ & $1 \cdot 9 / 0 \cdot 3$ \\
\hline \multirow{3}{*}{ C57BL/6 } & 1 & $0.5 /-$ & $0.2 /-$ & $0 /-$ & $1 /-$ & $0.7 /-$ & $1 /-$ \\
\hline & 2 & $0 \cdot 6 / 0$ & $0.5 / 0$ & $0 \cdot 2 / 0$ & $1 \cdot 3 / 0$ & $1 \cdot 2 / 0$ & $0.9 / 0$ \\
\hline & $\overline{6}$ & $0.7 / 0$ & $0 \cdot 1 / 0$ & $0 / 0$ & $1 \cdot 7 / 0$ & $1 / 0$ & $2 / 0$ \\
\hline \multirow[t]{3}{*}{ Balb/C } & 1 & $0 /-$ & $0 /-$ & $0 /-$ & $0 \cdot 2 /-$ & $0.2 /-$ & $0 /-$ \\
\hline & 2 & $0 \cdot 3 / 0$ & $0 \cdot 3 / 0$ & $0 / 0$ & $0 \cdot 2 / 0$ & $0 \cdot 1 / 0$ & $0 / 0$ \\
\hline & 6 & $0.6 / 0$ & $0 \cdot 2 / 0$ & $0 / 0$ & $0.7 / 0$ & $0 \cdot 1 / 0$ & $0 \cdot 1 / 0$ \\
\hline \multirow[t]{3}{*}{ CBA } & 1 & $0 \cdot 2 /-$ & $0 \cdot 2 /-$ & $0 /-$ & $0 /-$ & $0 /-$ & $0 /-$ \\
\hline & 2 & $0 \cdot 1 / 0$ & $0 \cdot 1 / 0$ & $0 / 0$ & $0 / 0$ & $0 / 0$ & $0 / 0$ \\
\hline & 6 & $0 \cdot 2 / 0$ & $0 / 0$ & $0 / 0$ & $0 \cdot 3 / 0$ & $0 \cdot 2 / 0$ & $0 / 0$ \\
\hline
\end{tabular}

Data shown as mean infected mouse score/uninfected mouse score.
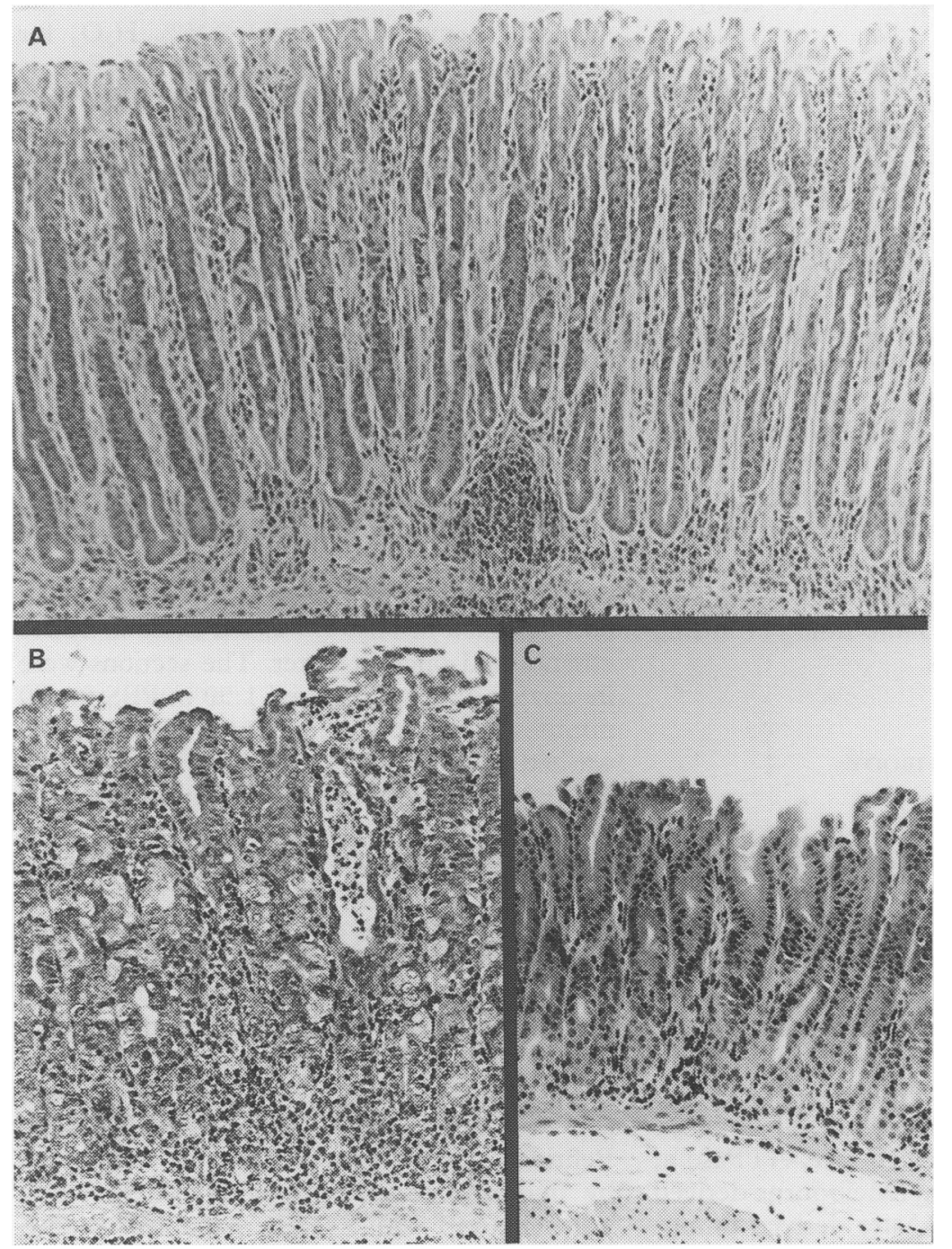

Figure 1: The gastric mucosa of SFL mice infected with $\mathrm{H}$ felis. (A) The body mucosa one month after infection showing loss of parietal and chief cells, replacement with proliferating cells, gland elongation, and mucus metaplasia. (haematoxylin and eosin stain, original magnification $\times 125$ ). (B) Microabscesses and cell infiltration of the gastric body two months after infection (haematoxylin and eosin stain, original magnification $\times 125$ ). (C) Antral mucosa six months after infection showing limited infiltration and no mucosal changes (haematoxylin and eosin stain, original magnification $\times 125$ ).
There was a severe chronic gastritis with pronounced activity in the body of the stomachs. One month after inoculation the body glands showed loss of parietal and chief cells and replacement by proliferating cells or mucus

infected with $H$ felis. The most severe degree of gastritis following infection occurred in the SJL strain; with large numbers of mononuclear cells (mainly lymphocytes) infiltrating the submucosa and lamina propria of the mucosa. secreting cells, or both (Fig 1A). Microabscesses in gastric pits were observed in some animals from two months after inoculation (Fig 1B). In contrast with these dominant pathological lesions in the body, only a mild to moderate degree of inflammation was observed in the antrum with no atrophic or metaplastic changes throughout the experiment (Fig 1C).

In the $\mathrm{C} 3 \mathrm{H} / \mathrm{He}$ strain of mice, the severity of gastritis increased with time and, by six months, all animals had severe gastritis with numerous chronic inflammatory cells in the lamina propria and submucosa in the body. Atrophic changes were especially prominent, in this strain of mice at six months after infection (Fig 2A). The glandular specialised cells were replaced by proliferating zone cells and mucus secreting epithelial cells, and these proliferating glands breached the muscularis mucosae in some mice. Isolated foci of atypical branching and dysplastic glands were observed (Fig 2B). Once again only mild to moderate chronic inflammation was seen in the antrum (Fig 2C).

Mice of the DBA $/ 2$ strain had a moderate gastritis by one to two months after inoculation of the $H$ felis. At six months, there was intensive infiltration by mononuclear inflammatory cells and polymorphs into the mucosa and submucosa and this was limited to the body. Atrophy with loss of parietal cells and the appearance of hyperplastic glands penetrating through the muscularis mucosae was a feature of some mice (Fig 3A).

The C57BL/6 mice also had a moderate degree of active gastritis. Loss of specialised cells at six months was observed in six mice with extensive hyperproliferation and moderate to severe glandular replacement in the body (Fig 3B). This was the most varied group with four of 10 mice showing little destructive inflammation.

$\mathrm{BALB} / \mathrm{c}$ mice had negligible gastritis at one and two months after infection, as observed previously. By six months, a mild degree of cellular infiltration was observed only in the antrum around gastric pits colonised by $H$ felis. No atrophic changes occurred in the corpus mucosa of these animals.

The least inflammation following $H$ felis infection was seen in the CBA mice, which showed no gastritis in the body (Fig $4 \mathrm{~A}$ ) or antrum (Fig 4B) during the whole term of the experiment despite excellent colonisation (Fig 4C).

Uninfected control mice of each of the six strains used remained $H$ felis free over the time of this study, and showed no notable changes in their gastric mucosa.

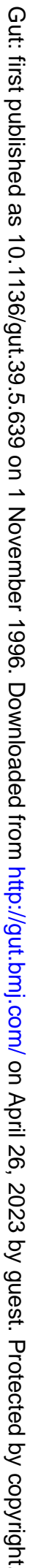

COLONISATION OF THE DIFFERENT MOUSE STRAINS WITH H FELIS

Table IV shows the levels of colonisation by $H$ felis in each strain. In SJL mice, a few animals 


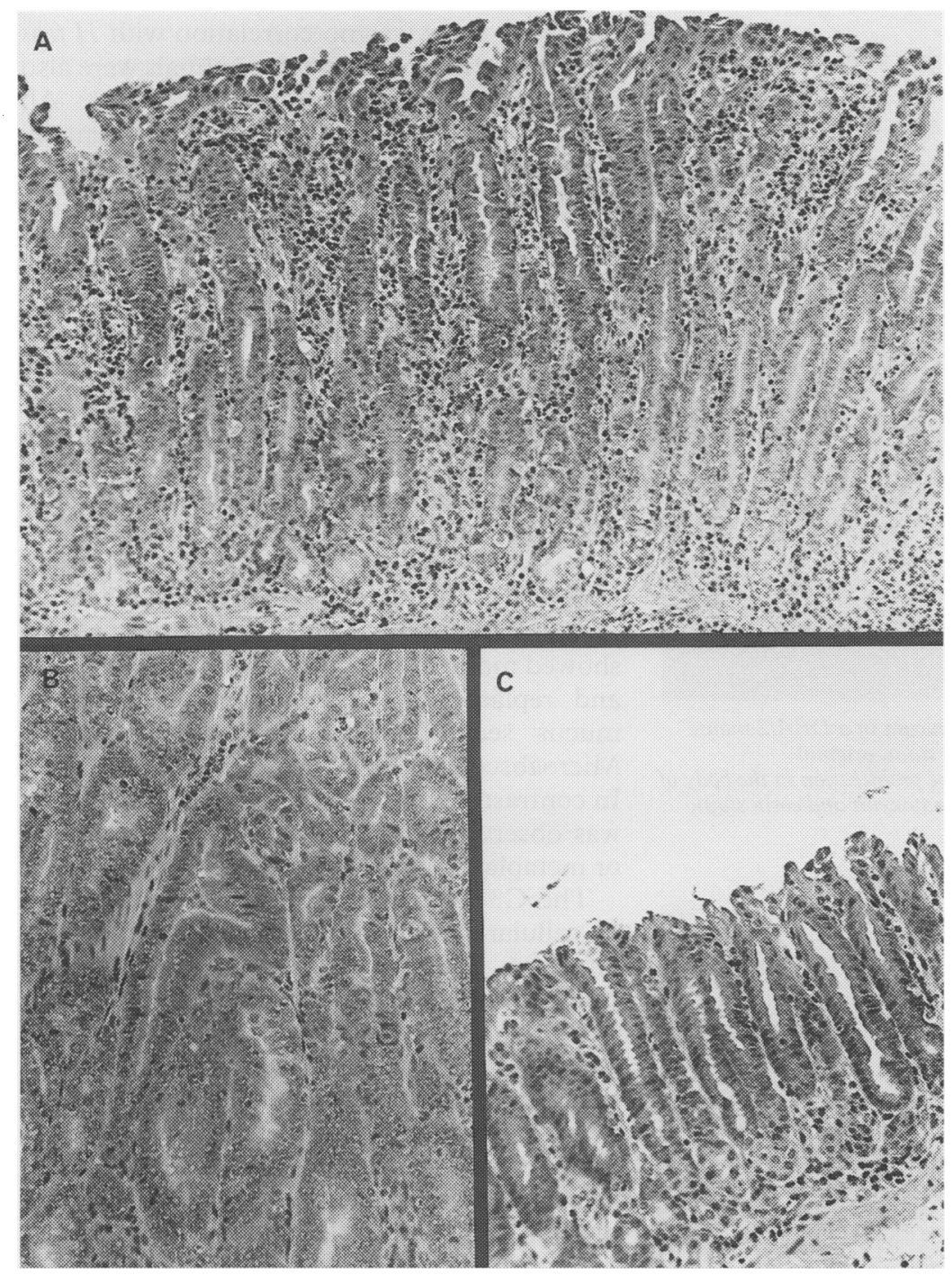

Figure 2: The gastric mucosa of $\mathrm{C} 3 \mathrm{H} / \mathrm{He}$ mice six months after infection with $\mathrm{H}$ felis. (A) Significant cell infiltration and atrophy with almost complete loss of specialised cells in the body mucosa (haematoxylin and eosin stain, original magnification $\times 125$ ). (B) $A n$ isolated focus of atypical and dysplastic glands (haematoxylin and eosin stain, original magnification $\times 200$ ). (C) Mild inflammation in the antral mucosa (haematoxylin eosin stain, original magnification $\times 125$ ).
TABLE IV Degree of colonisation by $\mathrm{H}$ felis of different strains of mice at various times after infection

\begin{tabular}{|c|c|c|c|c|}
\hline \multirow[t]{2}{*}{ Strain } & \multirow{2}{*}{$\begin{array}{l}\text { Length of } \\
\text { infection } \\
\text { (months) }\end{array}$} & \multicolumn{3}{|c|}{ Average score of colonisation } \\
\hline & & Antrum & Body & $S-C$ junction * \\
\hline \multirow[t]{3}{*}{ SJL } & 1 & $0 \cdot 3$ & 0.5 & 1 \\
\hline & 2 & $0 \cdot 3$ & 0 & 0 \\
\hline & 6 & 0.3 & 0 & 0 \\
\hline \multirow[t]{3}{*}{$\mathrm{C} 3 \mathrm{H} / \mathrm{He}$} & 1 & $1 \cdot 3$ & 0.2 & 0.3 \\
\hline & 2 & 1.4 & 0.7 & 0.9 \\
\hline & 6 & 0.1 & 0 & 0 \\
\hline \multirow[t]{3}{*}{$\mathrm{DBA} / 2$} & 1 & 2 & 0.7 & 2 \\
\hline & 2 & $1 \cdot 8$ & 0.6 & 1 \\
\hline & 6 & $0 \cdot 1$ & 0 & 0 \\
\hline \multirow[t]{3}{*}{ C57BL/6 } & 1 & $2 \cdot 7$ & 1 & 1 \\
\hline & 2 & $2 \cdot 1$ & 1 & 1.4 \\
\hline & 6 & 1.5 & 0.7 & 0.5 \\
\hline \multirow[t]{3}{*}{$\mathrm{BALB} / \mathrm{c}$} & 1 & $2 \cdot 7$ & 0.2 & 0 \\
\hline & 2 & $2 \cdot 9$ & $0 \cdot 1$ & 0.2 \\
\hline & 6 & $3 \cdot 2$ & $0 \cdot 1$ & 0.5 \\
\hline \multirow[t]{3}{*}{ CBA } & 1 & 3 & $0 . \overline{7}$ & 1 \\
\hline & 2 & $3 \cdot 4$ & 0.5 & $1 \cdot 3$ \\
\hline & 6 & 3.9 & 0.4 & 0.8 \\
\hline
\end{tabular}

$\star S-C$ junction: squamo-columnar junction, - that is, cardia equivalent.

point after infection. At the beginning mice had good antral colonisation but, as atrophy developed, their number in the antrum declined. There was thus a negative correlation between antral colonisation and body atrophy. In Table IV, it appears as though the figures for the SJL and C57BL/6 mice are in conflict with the general rule. This is not the case. With respect to the SJL mouse, major pathology develops rapidly - that is, at one month there is already substantial atrophy and the level of colonisation is much reduced. Using a three point scale as described in the Methods and averaging the results per mouse, a grading of 0.3 means virtually no bacteria are seen. The results with the C57BL/6 mice do seem inconsistent but this relates (as pointed out above) to the variable pathology in these mice, four of 10 mice showing virtually no atrophy. Also in this group the pathology (when present) develops early and consequently the level of colonisation is lower than other strains. This together with the effect of averaging seems to show no influence of atrophy on colonisation. In fact, looking at individual mice within this group the observation holds up that is, in the four mice without atrophy there is still moderate colonisation of the antrum. in moderate colonisation in their antrum at one and two months, but few bacteria were detected at six months. DBA/2 mice also had heavy colonisation in the antrum and cardia at one and two months but the bacteria had disappeared at six months. While most C57BL/6 mice had heavy colonisation in antrum, body, and cardia at one and two months; only four mice had heavy colonisation in the antrum at six months. The mice with atrophy were the animals found to have lost the infection.

In contrast with the four strains above that all showed significant pathology and appeared to lose their helicobacters, in both the BALB/c and CBA strains, mice that showed virtually no pathology associated with infection, all mice have heavy colonisation in their antrum throughout the experiment, with moderate colonisation of the cardia. Indeed, there seemed to be an increase in colonisation in these animals with time.

All strains of mice showed very little colonisation of the body of the stomach at any time
SEROLOGY OF INFECTED MICE

Table $\mathrm{V}$ shows the serum levels of anti- $H$ felis antibody (IgG) measured by ELISA. All infected mice had significantly higher levels of antibody compared with uninfected control mice in each strain. There was a tendency for the levels of antibody to increase with time after infection, however there was no correlation between the severity of the inflammatory response and the level of antibody. The only strain of mice that appeared to have different levels of anti- $H$ felis antibody were the CBA mice, which had a reduced response.

ASSESSMENT OF AUTOIMMUNITY IN H FELIS INFECTED MICE

Table VI shows the results of assessment of sample mice of various strains for antibody 


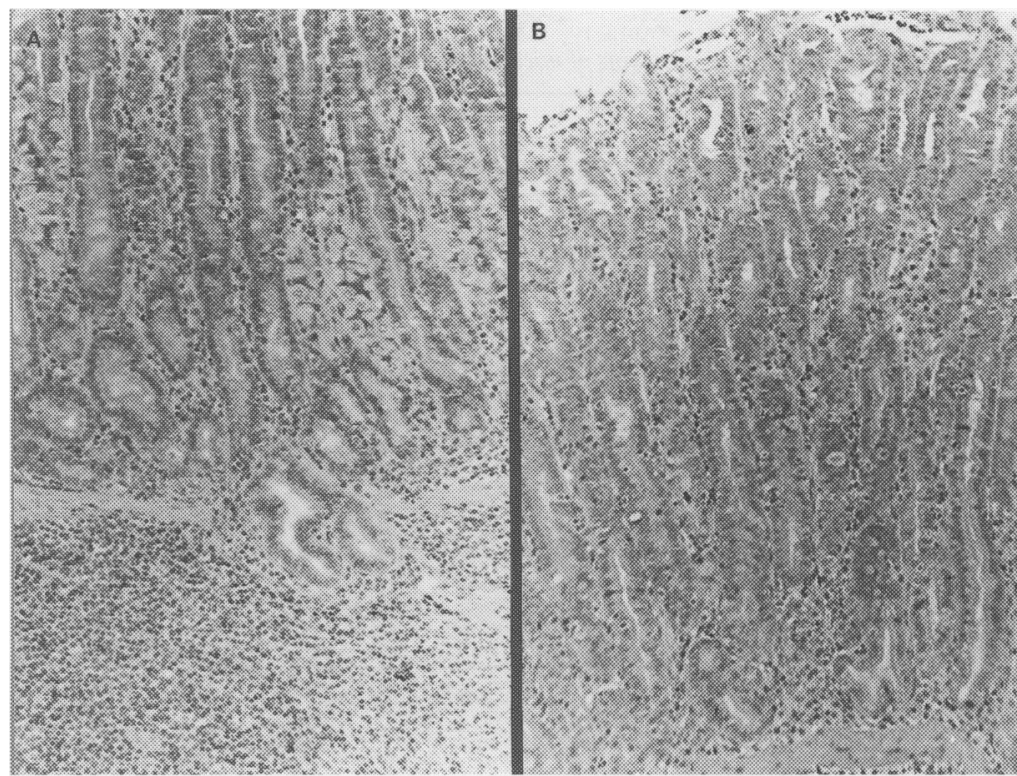

Figure 3: (A) Hyperplastic glands penetrating the muscularis mucosa in a $D B A / 2$ mouse six months after infection with $\mathrm{H}$ felis (haematoxylin and eosin stain, original magnification $\times 125)$. (B) Loss of specialised cells with extensive proliferation in the body of a C57BL/6 mouse six months after infection with $\mathrm{H}$ felis (heamatoxylin and eosin stain, original magnification $\times 125$ ).
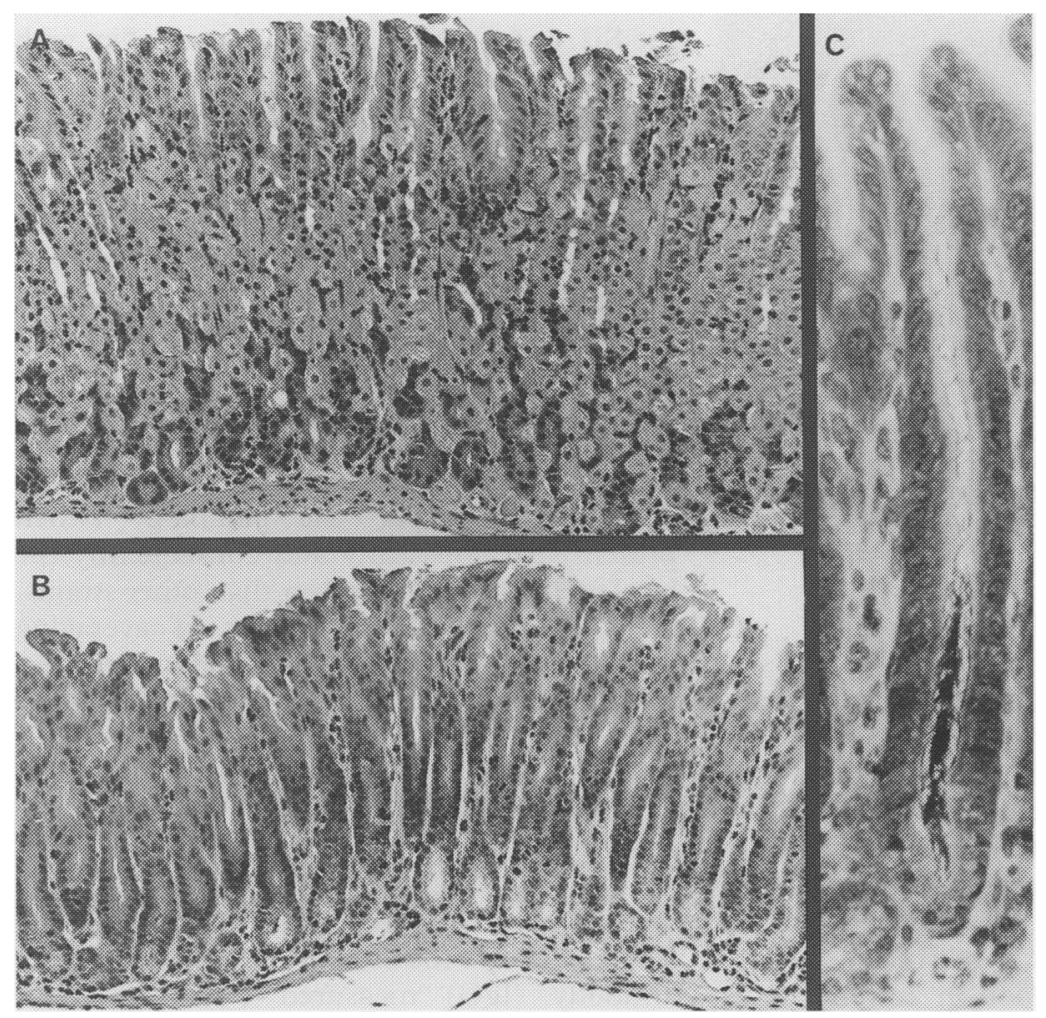

Figure 4: The gastric mucosa of a $C B A$ mouse after six months infection with $\mathrm{H}$ felis. (A) Body mucosa with normal histology (haematoxylin and eosin stain, original magnification $\times 125$ ). (B) Antral mucosa with normal histology (haemtoxylin and eosin stain, original magnification $\times 125)$. (C) Heavy colonisation of an antral pit with $\mathrm{H}$ felis (May Grunwald Giemsa original magnification stain, original magnification $\times 625$ ).

against the $\mathrm{H}^{+} / \mathrm{K}^{+}$ATPase parietal cell acid pump or against other exposed tissue antigens. No anti-parietal cell antibody was seen by ELISA or immunostaining in either infected or uninfected SJL, DBA/2 or BALB/c mice. Some autoimmune antibody directed against the purified $\mathrm{H}^{+} / \mathrm{K}^{+}$ATPase and parietal cells was revealed by reaction of serum from $\mathrm{C} 3 \mathrm{H} / \mathrm{He}$ mice with the normal uninfected mouse tissue.
However, there was no correlation with $H$ felis infection as antibody positive animals were also seen in the control uninfected group. All positive control sera from experimentally induced autoimmune mice showed antibody by both techniques.

H PYLORI INFECTION IN MICE

Table VII shows the severity of gastritis in two strains of mice infected with $H$ pylori. The most severe degree of gastritis after $H$ pylori infection occurred in the C57BL/6 strain, with a moderate to severe chronic gastritis with activity detectable in the corpus of the stomach (Fig 5A). Interestingly, there was not the variability in pathology in the C57/BL/6 mice colonised with $H$ pylori compared with that observed with $H$ felis. Six months after infection body glands showed moderate loss of parietal and chief cells and replacement with proliferating cells or mucus secreting cells, or both (Fig 5B). Microabscesses in gastric pits were also seen. In contrast, only a mild degree of inflammation was observed in the antrum with no atrophic or metaplastic changes detected (Fig 5C).

The $\mathrm{C} 3 \mathrm{H} / \mathrm{He}$ mice exhibited a mild degree of cellular infiltration following a six month infection (Fig 5D). Almost no atrophic changes occurred in the body of the stomach. Uninfected control animals of each of the strains used remained $H$ pylori free over the time of this study, with no change in the gastric mucosa observed. Thus similar results were found to the $H$ felis infected C57/BL/6 mouse in that atrophy in the body was seen after six months and the degree of colonisation reduced. In contrast with the $H$ felis infected $\mathrm{C} 3 \mathrm{H} / \mathrm{He}$ mouse atrophy was not seen in the longterm infected animals.

\section{Discussion}

These longterm studies clearly show the importance of host differences in the development of Helicobacter induced pathology. Basically the $H$ felis infected mice could be divided into two groups. Those who exhibited little or no inflammatory response and those who displayed a severe gastritis with atrophy. In the SJL, C3H/He, C57BL/6, and DBA/2 strains a moderate to severe degree of chronic active gastritis was observed in the body of the stomach, with replacement of parietal and chief cells with proliferating zone cells or mucous secreting cells, or both, by six months after infection. On the other hand, atrophic changes were not detectable in the body of BALB/c and CBA mice. BALB/c mice had only a mild degree of localised gastritis around the gastric pits in the antrum, but not in the body. CBA mice had no observable gastritis. Histopathological findings of all 216 slides in this experiment were 'blinded' and therefore unbiased. The progressive results are considered to be an accurate representation of the developing gastritis. Probably the most revealing feature of the gastritis was its predominance in the body mucosa of affected animals with virtually no inflammatory or 
TABLE $\mathrm{v}$ Levels of specific antibody (IgG) against $\mathrm{H}$ felis as determined by ELISA in mouse serum from different strains of mice at various times after infection

\begin{tabular}{|c|c|c|c|c|c|}
\hline \multirow[t]{3}{*}{ Strain } & \multicolumn{5}{|c|}{ Mean value of optical density reading (SD) } \\
\hline & \multirow{2}{*}{$\frac{1 \text { month }}{\text { infected }}$} & \multicolumn{2}{|l|}{2 months } & \multicolumn{2}{|l|}{6 months } \\
\hline & & control & infected & control & infected \\
\hline $\begin{array}{l}\text { SJL } \\
\text { C3H/He } \\
\text { DBA/2 } \\
\text { C57BL/6 } \\
\text { BALB/c } \\
\text { CBA }\end{array}$ & $\begin{array}{l}2.15(0.07) \\
1.40(0.16) \\
1.91(0.25) \\
1.22(0.15) \\
1.62(0.35) \\
0.75(0.19)\end{array}$ & $\begin{array}{l}0.09(0.03) \\
0.09(0.05) \\
0.12(0.05) \\
0.06(0.01) \\
0.08(0.03) \\
0.08(0.01)\end{array}$ & $\begin{array}{l}2.23(0.19) \\
1.47(0.24) \\
1.87(0.27) \\
1.45(0.29) \\
1.53(0.33) \\
0.94(0.35)\end{array}$ & $\begin{array}{l}0.17(0.01) \\
0.27(0.17) \\
0.08(0.04) \\
0.27(0.28) \\
0.10(0.07) \\
0.42(0.26)\end{array}$ & $\begin{array}{l}2.61(0.08) \\
2.16(0.33) \\
1.89(0.27) \\
1.75(0.12) \\
2.17(0.16) \\
1.42(0.27)\end{array}$ \\
\hline
\end{tabular}

TABLE VI Assessment of antibody mediated autoimmunity in $\mathrm{H}$ felis infected mice at different times after infection

\begin{tabular}{llll}
\hline $\begin{array}{l}\text { Mouse } \\
\text { strain }\end{array}$ & $\begin{array}{l}\text { Infection with } \\
\text { H felis }\end{array}$ & $\begin{array}{l}H^{+} / K^{+} \text {ATPase } \\
\text { antibody }\end{array}$ & $\begin{array}{l}\text { Parietal cell } \\
\text { antibody }\end{array}$ \\
\hline C3H/He & Nil & $3 / 6$ & $3 / 6$ \\
& 2 months & $2 / 9$ & $2 / 9$ \\
SJL & 6 months & $4 / 10$ & $3 / 10$ \\
& Nil & $0 / 6$ & $0 / 6$ \\
DBA/2 & 2 months & $0 / 10$ & $0 / 10$ \\
& 6 months & $0 / 10$ & $0 / 10$ \\
BALB/c & Nil & $0 / 6$ & $0 / 6$ \\
& 2 months & $0 / 10$ & $0 / 10$ \\
& N months & $0 / 10$ & $0 / 10$ \\
Positive control & 2 months & $0 / 6$ & $0 / 6$ \\
Negative control & - & $0 / 10$ & $0 / 10$ \\
mAB IH9 & - & $3 / 3$ & $0 / 10$ \\
mAB 2B6 & - & $0 / 3$ & $3 / 3$ \\
& - & $1 / 1$ & $0 / 3$ \\
\hline
\end{tabular}

*Serum from neonatally thymectomised mice. $†$ Antibody against the a subunit of gastric $\mathrm{H}^{+} / \mathrm{K}^{+}$ATPase. $\ddagger$ Antibody against the $b$ subunit of gastric $\mathrm{H}^{+} / \mathrm{K}^{+}$ATPase.

architectural changes in the antrum. Given what we now know about the colonisation patterns of $H$ felis in mice, the distribution of gastritis is anomalous. ${ }^{12} \mathrm{H}$ felis has a more limited ecological niche in the stomach than $H$ pylori. The bacterium is mainly restricted to the antrum of the stomach and the cardia equivalent - that is, the three to four gastric glands immediately distal to the squamocolumnar junction close to the oesophagus and the stratified epithelial lined rumen-like compartment of the mouse stomach. The antrum and cardia have one feature in common; the absence of parietal cells. We have argued elsewhere, that this is due to the sensitivity of the bacterium to local acid production. ${ }^{13}$ One exception to the poor colonisation of the body mucosa by $H$ felis was in the C57BL/6 mice, which had moderate to heavy colonisation. This is an interesting difference that warrants further investigation but does detract from the main observation that in general progressive changes occurred in the presence of the lightest bacterial load.

Although the antrum is the preferred habitat of $H$ pylori in the human stomach the organism is seen overlying the body. The atrophic and metaplastic gastritis reported in this paper occurs where few bacteria are seen and yet the organism can readily be seen in the antrum in the early stages of infection. This means that the damage seen in body mucosa cannot be due to inflammatory reactions directed against the bacterium itself, otherwise antral destruction would be seen. One explanation for this phenomenon is that the damage results from an autoimmune response directed against gastric tissue and triggered by the presence of longterm $H$ felis infection.

Gastric tissue is known to be susceptible to autoimmune attack. In the human, chronic atrophic gastritis of the corpus mucosa (type A gastritis), is the underlying basis for pernicious anaemia and is characterised by the generation of autoantibodies against the $\mathrm{H}^{+} / \mathrm{K}^{+}$ATPase enzyme, the gastric proton pump of the parietal cell, together with mononuclear cell infiltration within the gastric mucosa. ${ }^{14} 15$ Autoimmune gastritis can be induced experimentally in certain strains of mice by neonatal thymectomy. ${ }^{16}$ In both human autoimmune gastritis and the mouse model, $\mathrm{H}^{+} / \mathrm{K}^{+}$ATPase antibodies can be detected in the serum. For this reason $\mathrm{H} / \mathrm{K}$ ATPase antibodies were assessed in the $H$ felis infected mice but with completely negative results. However, this observation does not eliminate the possibility of an autoimmune response, as there is animal model of autoimmune gastritis without demonstration of parietal cell antibodies. Nishio et al isolated a $T$-cell clone reactive to parietal cells from a mouse with autoimmune gastritis and adoptively transferred these activated cells into syngenetic nude mice. Autoimmune gastritis was seen at four weeks in the recipient mice without the production of autoantibodies to parietal cells. ${ }^{17}$ An incidental finding in this study was the presence of some parietal cell antibody in the uninfected $\mathrm{C} 3 \mathrm{H} / \mathrm{He}$ mice. This is unexplained but may be of interest to those working with the thymectomised mouse models. In a recent finding of relevance to this study, Appelmelk and colleagues showed shared epitopes between $H$ pylori LPS and Lewis $\mathrm{x}$ and $\mathrm{y}$ blood antigens. ${ }^{18}$ Experimental infection in mice or natural infection in humans induced anti-Lewis antibodies. The $\beta$ chain of gastric $\mathrm{H}^{+}, \mathrm{K}^{+}$-ATPase and the parietal cell proton pump were shown to contain Lewis y epitopes with gastric mucin containing both Lewis $x$ and $y$ determinants. They conclude that molecular mimicry between $H$ pylor $i$ LPS and the host, based on Lewis antigens, provides an understanding of an autoimmune basis to $H$ pylori gastritis. We do not yet know if $H$ felis LPS also shares such epitopes. Investigations into similar phenomena in the mouse model described above will be interesting.

TABLE VII Mean grading of gastritis and levels of colonisation in different mice strains infected with $\mathrm{H}$ pylori

\begin{tabular}{|c|c|c|c|c|c|c|c|c|}
\hline \multirow{2}{*}{$\begin{array}{l}\text { Strain/length } \\
\text { colonisation }\end{array}$} & \multicolumn{3}{|l|}{ Antrum } & \multicolumn{3}{|l|}{ Body } & \multicolumn{2}{|c|}{ Colonisation (average score) } \\
\hline & Inflammation & Activity & Atrophy & Inflammation & Activity & Atrophy & Antrum & Body \\
\hline $\mathrm{C} 3 \mathrm{H} / \mathrm{He} 2 \mathrm{~m}$ & $0 \cdot 7$ & 0 & 0 & 0.3 & 0 & 0 & $1 \cdot 8$ & $0 \cdot 17$ \\
\hline $\mathrm{C} 3 \mathrm{H} / \mathrm{He} 6 \mathrm{~m}$ & 0.9 & $0 \cdot 6$ & 0 & $1 \cdot 3$ & 0.5 & $0 \cdot 3$ & 1.9 & $0 \cdot 6$ \\
\hline $\mathrm{C} 57 \mathrm{BL} / 63 \mathrm{~m}$ & 0.5 & 0.5 & 0 & 0.9 & 0.5 & $0 \cdot 3$ & $2 \cdot 6$ & $0 \cdot 1$ \\
\hline C57BL $66 \mathrm{~m}$ & $1 \cdot 5$ & $0 \cdot 8$ & 0 & $2 \cdot 0$ & $1 \cdot 4$ & 1.5 & 0.9 & $0 \cdot 4$ \\
\hline
\end{tabular}




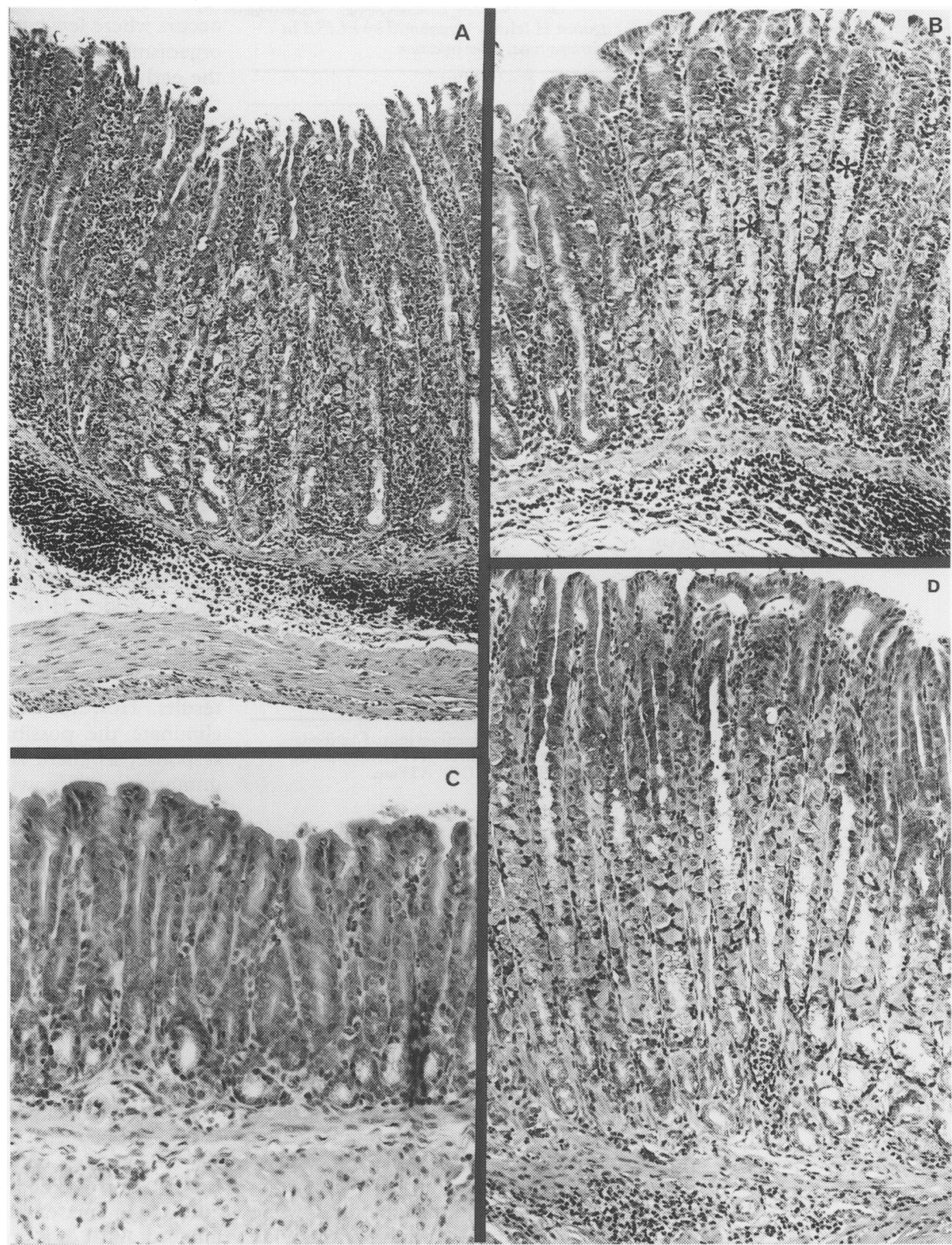

Figure 5: The gastric mucosa of mice colonised with $\mathrm{H}$ pylori for six months. (A) Body mucosa of a C57BL/6 mouse showing moderate infiltration of inflammatory cells (haematoxylin and eosin stain, original magnification $\times 125$ ). (B) Body mucosa of a C57BL/6 mouse showing the replacement of parietal and chief cells with proliferating or mucus secreting cells, or both $(*)$ (haematoxylin and eosin stain, original magnification $\times 125)$. (C) Antral mucosa of a C57BL/6 with normal histology (heamatoxylin and eosin stain, original magnification $\times 125$ ). (D) Body mucosa of a C3H/He mouse a mild degree of cellular infiltration (heamatoxylin and eosin stain, original magnification $\times 125$ ).

A contribution of autoimmunity to $H$ pylori mediated damage has been previously discussed in the published reports. Negrini demonstrated the presence of antibody directed against various mouse tissues after intensive parenteral immunisation of mice with $H$ pylori antigens. ${ }^{19} 20$ Although an artificial experimental system, it shows that cross reactive epitopes may exist between the bacterium and gastric tissue. There has been discussion of a possible role of $H$ pylori in human autoimmune gastritis but the association is at present unclear. The organism is usually absent from the gastric mucosa of patients although antibody against $H$ pylori has been detected in their serum. ${ }^{21} 22$ Our results may be relevant to this debate as continuing damage is seen in the mouse at the same time as bacteria are lost from the mucosa.

There are some features of the atrophic gastritis seen here that are different to classic Type A atrophy in the human, these need to be explained. Glands show metaplasia rather than destruction and the replacement of specialised cells does not seem to be directed as a consequence of a reaction against the parietal and chief cells themselves as there are no intraepithelial accumulations of mononuclear 
cells. Rather the effect seems to be due to hyperplastic changes in the mucous neck cells with downward replacement of specialised cells - that is, a divergent differentiation of proliferating neck cells away from parietal/chief cell lineage. This may explain the lack of parietal cell antibody. It could be, however, that similar mucosal changes are a feature of the atrophy associated with non-autoimmune active/chronic gastritis. Another difference from Type A gastritis is the very considerable infiltration of polymorphonuclear cells in all the reactive strains of mice. Given that we could see no $H$ felis in this actively inflamed body tissue, we have no explanation as to what is the stimulus for recruitment of these cells.

However, the major differences between this $H$ felis associated atrophic gastritis and the situation in the $H$ pylori infected human is that there is no prior or accompanying phase of active/chronic gastritis in the antrum or body. Correa, the originator of the currently accepted pathway from gastritis to gastric adenocarcinoma, has himself questioned whether diffuse antral gastritis and multifocal atrophic gastritis are separate entities or part of the same spectrum. ${ }^{23}$ These data would strongly suggest they are separate entities albeit both caused by $H$ pylori. For an unknown reason Helicobacter species in mice do not usually induce an active/ chronic gastritis in antrum or body directly related to the presence of the bacterium. However, atrophy with some of the features seen in humans does occur. Importantly this aspect of helicobacter induced inflammation is host dependent. In the human with more bacteria throughout the corpus mucosa and gastritis consistently in the antrum, it is very difficult to dissociate these two entities. These mouse models allow that to be done. The results of the small scale experiment with our mouse adapted strain of $H$ pylori show that the same phenomenon occurs confirming the relevance of the $H$ felis data.

- Humans infected with $H$ pylori who develop severe gastritis in the body accompanied by loss of acid secretion lose the bacterium. ${ }^{7}$ The same is seen here in the longterm $H$ felis and $H$ pylori infected mice. As the atrophy develops the infecting organism is lost from the stomach. In $\mathrm{C} 3 \mathrm{H} / \mathrm{He}, \mathrm{C} 57 \mathrm{BL} / 6$ and $\mathrm{DBA} / 2$ mice at the last time point examined $H$ felis was not present. SJL mice were never well colonised. In contrast, a high rate of colonisation was seen in $\mathrm{BALB} / \mathrm{c}$ and $\mathrm{CBA}$ mice throughout the entire experiment. Thus, the degree of $H$ felis colonisation in mice was inversely proportional to the severity of the gastritis. One explanation for this observation could be that immunity against the bacteria was increased because of the inflammation and so an effective antibacterial state was induced with time. This would seem unlikely given the inability of normal immune responses to eliminate $H$ pylor from infected people and the finding that there was no difference in the serological responses to $H$ felis in any mice except the CBA mice, which did have a reduced response. The other explanation could be that local environmental changes induced by the atrophy could be making the stomach inhospitable for $H$ felis or $H$ pylori. This could result from competition due to overgrowing other bacteria associated with a hypochlorhydric state or from the cidal effects of a relatively alkaline environment on a bacterium adapted to survival in the presence of some acid. Similar arguments have been suggested for the loss of $H$ pylori from humans with atrophic gastritis. ${ }^{7}$

Why are there such striking differences in response between mouse strains? One explanation could relate to the immunoreactivity of each strain. Mouse strains of varying haplotypes were selected for this experiment in anticipation of this hypothesis (H-2 complex: major histocompatibility I and II). But C3H/ $\mathrm{He}$ and CBA strains belong to the $\mathrm{H}-2 \mathrm{k}$ haplotypes while BALB/c and DBA/2 strains belong to $\mathrm{H}-2 \mathrm{~d}$ haplotype. The significant differences in the severity and type of gastritis between these identical $\mathrm{H}-2$ complex strains suggests there is no relation between severity of gastritis and H-2 complex. Another explanation for the difference relates to prior antigen exposure. However, the mouse strains were selected from the same animal house and so it is probable that the gut microbiotas are similar but this has not been proved to date. Much more comparative work is needed before we understand the true nature of these differences in host responsiveness. Why little or no inflammation is seen in the antrum of any of the mouse strains infected with either $H$ felis or the cagA positive mouse adapted $H$ pylori strain is also a mystery. Indeed, true antral active/ chronic gastritis is rarely seen in any helicobacter infected animal of any species other than the human.

A short-term study of $H$ felis infection in $\mathrm{BALB} / \mathrm{C}, \mathrm{C} 3 \mathrm{H} / \mathrm{He}$, and $\mathrm{C} 57 \mathrm{BL} / 6$ mice has recently been reported by Mohammadi and colleagues. ${ }^{24}$ They demonstrated differences in pathology at 11 weeks similar to our study. They noted BALB/c mice showed little inflammation whereas $\mathrm{C} 3 \mathrm{H} / \mathrm{He}$ and $\mathrm{C} 57 \mathrm{BL} / 6$ animals had significant scores although atrophy had not yet developed. C57BL/6 has 10 times more bacteria in the body as was found here. Additionally, they studied a series of congenic mice and concluded that there are contributions by both MHC and non-MHC genes to helicobacter induced inflammation.

The results from these animal studies challenge the conventional wisdom regarding the evolution of atrophic gastritis and suggest that host dependent autoimmune type mechanisms could contribute. Rather than atrophy being an extreme end point of a continuum of inflammation starting with acute gastritis, leading through active/chronic gastritis to atrophic gastritis, an independent mechanism of induction of multifocal atrophic gastritis may occur in some people. In the human this atrophy is seen together with the chronic gastritis resulting from direct action of the bacteria and so the two phenomena cannot be distinguished. The $H$ felis and $H$ pylori mouse models will allow investigation of the mechanism of parietal and chief cell replacement, reasons for helicobacter loss in the atrophic 
stomach, and identification of the host factors responsible for host dependent atrophy.

This work was supported by a grant from the National Health and Medical Research Council, Australia and Astra Hassle, Sweden. Dr Sagakami was funded through the Vehara Foundation Scholarship of the Taisho Foundation.

1 Correa P. The gastric precancerous process. Cancer Surv $1983 ; 2 \cdot 437-50$.

2 IARC. IARC Monographs on the evaluation of carcinogenic risks to humans. Vol 61. Lyon: World Health Organisation, 1994: $177-240$

3 Covacci A, Censini S, Bugnoli M, Petracca R, Burroni D, Macchia G, et al. Molecular characterization of the $128-\mathrm{kDa}$ immunodominant antigen of Helicobacter pylor associated with cytotoxicity and duodenal ulcer. Proc Nat Acad Sci USA 1993; 90: 5791-5.

4 Tummuru MKR, Cover TL, Blaser MJ. Cloning and expression of a high-molecular-mass major antigen of Helicobacter pylori - evidence of linkage to cytotoxin production. Infect Immun 1993; 61: 1799-809.

5 Crabtree JE, Farmery SM. Helicobacter pylori and gastric mucosal cytokines - evidence that cag $A$-positive strains mucosal cytokines - evidence that cagA-positive

6 CrabtreeJE, Covacci A, Farmery SM, XiangZ, Tompkins DS, Perry S, et al. Helicobacter pylori induced interleukin-8 expression in gastric epithelial cells is associated with CagA positive phenotype. $\mathcal{F}$ Clin Pathol 1995; 48: 41-5.

Siurala M, Sipponen P, Kekki M. Campylobacter pylori in a sample of Finnish population: relations to morphology and functions of the gastric mucosa. Gut 1988; 29: 909-15.

8 Lee A, Chen MH, Coltro N, O'Rourke J, Hazell S, Hu PJ, et al. Long term infection of the gastric mucosa with Helicobacter species does induce atrophic gastritis in an animal model of Helicobacter pylori infection. Int $\mathcal{F}$ Med Microbiol 1993; 280: 38-50.

9 Enno A, O'Rourke JL, Howlett CR, Jack A, Dixon MF, Lee A MALToma-like lesions in the murine gastric mucosa after long-term infection with helicobacter felis - a mouse long-term infection with helicobacter felis - a mouse model of Helicobacter pylori-ind

10 Chuang JS, Callaghan JM, Gleeson PA, Toh B. Diagnostic ELISA for parietal cell autoantibody using tomato lectinpurified gastric $\mathrm{H}^{+} / \mathrm{K}^{+}$-ATPase (proton pump). Autoimmunity 1992; 12: 1-7.

11 Alderuccio F, Toh B, Tan S, Gleeson PA, van Driel IR. An autoimmune disease with multiple molecular targets abrogated by the transgenic expression of a single autoantigen in the thymus. $\mathcal{F}$ Exp Med 1993; 178: 419-26.

12 Danon SJ, O'Rourke JL, Moss ND, Lee A. The importance of local acid production in the distribution of Helicobacter felis in the mouse stomach. Gastroenterology 1995; 108: 1386-95.

13 Lee A, Dixon MF, Danon SJ, Kuipers E, Megraud F, Larsson $\mathrm{H}$, et al. Local acid production and Helicobacter pylori: a unifying hypothesis of gastroduodenal disease. pylori: a unifying hypothesis of gastroduoder

14 Karlsson KA, Burman P, Loof L, Mardh S. Major parietal cell antigen in autoimmune gastritis with pernicious anaemia is the acid producing $\mathrm{H}+, \mathrm{K}+$-adenosine triphosphatase of the stomach. $\mathcal{F}$ Clin Invest 1988; 81: 475-9.

15 Strickland RG, Baur S, Ashworth LAE, Taylor KB. A correlative study of immunological phenomena in pernicious anaemia. Clin Exp Immunol 1971; 8: 25-36.

16 Kojima A, Prehn RT. Genetic susceptibility of postthymectomy autoimmune diseases in mice. Immunogenetics 1981; 14: 15-27.

17 Nishio A, Hosono $M$, Watanabe Y, Sakai M, Okuma $M$, Masuda T. A conserved epitope on $\mathrm{H}-, \mathrm{K}+$-adenosine triphosphatase of parietal cells discerned by a murine triphosphatase of parietal cells discerned by a murine gastritogenic

18 Appelmack BJ, Simoons-Smit I, Negrini R, Moran AP, Aspinall GO, Forte JG, et al. Potential role of molecular mimicry between Helicobacter pylori liposaccharide and host Lewis blood group antigens in autoimmunity. Infect Immun 1996; 64: 2031-40.

19 Negrini R, Lisato L, Zanella I, Cavazzini L, Gullini S, Villanacci $\mathrm{V}$, et al. Helicobacter pylori infection induces antibodies cross-reacting with human gastric mucosa. Gatroenterology 1991; 101: 437-45.

20 Negrini R, Poiesi C, Savio A, Paterlini A, Buffoli F, Cesari P, et al. Molecular mimicry of gastric antigens by Helicobacter pylori: a role in the pathogenesis of atrophic gastritis? [Abstract]. Am $\mathcal{F}$ Gastroenterol 1994; 89: 1329.

21 Faisal MA, Russell RM, Samloff IM, Holt PR. Helicobacter pylori infection and atrophic gastritis in the elderly. pylori infection and atrophic gastr
Gastroenterology 1990; 99: 1543-4.

22 Karnes WEJ, Samloff IM, Siurala M, Kekki M, Sipponen P, Kim SW, et al. Positive serum antibody and negative tissue staining for Helicobacter pylori in subjects with atrophic body gastritis. Gastroenterology 1991; 101: 167-74.

23 Correa P, Miller M. Helicobacter pylori and gastric atrophy - cancer paradoxes. $\mathcal{F}$ Natl Cancer Inst 1995; 87: 1731-2.

24 Mohammadi M, Redline R, Nedrud J, Czinn S. Role of the host in pathogenesis of Helicobacter-associated gastritis $H$. felis infection of inbred and congenic mouse strains. Infect Immun 1996; 64: 238-45. 